Бахов Иван. Особенности использования платформы “Translator's amanuensis 2020" переводчиками как средства постредактирования.Учитывая важность подготовки переводчиков к работе в условиях современного рынка труда, особый интерес представляют наработки ученых в таких аспектах их профессиональной подготовки, как информационно-тематический, информационно-поисковый, информационно-технологический. В статье проведен анализ публикаций зарубежных авторов посвященных интернет платформе «Translator's Amanuensis 2020» (ТА -2020) как средства постредактирования переведенных текстов, оценены приоритетные направления исследований ученых по данной проблеме за первое десятилетие XXI века. Проанализирована роль системы машинного перевода в профессиональной деятельности переводчика как средства интерперсональной коммуникации. Проведено сравнение взаимодействия системы машинного перевода в процессе выработки текста и традиционных форм изменений переводчиков-людей. Указано на изменении парадигмы, которая происходит в переводе, и тем, что происходит с традиционными носителями информации. Отмечаются тенденции растущего интереса к разработке средств, ориентированных на перевод, и приложений для улучшения поиска надежных источников информации, терминологических ресурсов, специализированных словарей, глоссариев. Подчеркнуто, что разработка когнитивных характеристик ТА-2020 опирается на когнитивные исследования в области постредактирования в рамках проектов CASMACAT и SEECAT. Некоторые характеристики ТА-2020 предусматривают наличие передовых методов поиска и обработки данных, сложных приложений для отслеживания движения глаз, методов измерения когнитивных усилий и способности обрабатывать и анализировать выборки. Некоторые характеристики ТА-2020 требуют от людей психологической адаптации, такой как улучшенная способность обрабатывать мультимодальную информацию, и адаптироваться к новым парадигмам считывания. Отмечено, что остаются и менее исследованные пути, такие как, например, различные способы интеграции основных понятий переводоведения в сферу машинного перевода - это такие понятия, как модели переводческой компетенции, категоризации проблем перевода, социологические и этические вопросы.

Ключевые слова: средства перевода, постредактирование, перевод с использованием компьютера, системы памяти перевода, машинный перевод, повторное посредничество.

Bakhov Ivan. Peculiarities of Using the "Translator's Amanuensis 2020 Platform" by Translators as a Means of Postediting. Given the importance of training translators to work in today's labor market, of particular interest are the achievements of scientists in such aspects of their training as information-thematic, information-search, informationtechnological. The article analyzes the publications of foreign authors on the Internet platform "Translator's Amanuensis 2020 " as a means of editing translated texts, assesses the priority areas of research on this issue in the first decade of the XXI century. The role of the machine translation system in the professional activity of a translator as a means of interpersonal communication is analyzed. A comparison of the interaction of the machine translation system in the process of text production and traditional forms of editing human translators is made. It is stressed on the paradigm shift that occurs in translation and what happens to traditional media. Emphasis is placed on the growing interest in the development of translation-oriented tools and applications to improve the search for reliable sources of information, terminological resources, specialized dictionaries, and glossaries. It is emphasized that the development of cognitive characteristics of TA-2020 is based on cognitive research in the field of post-editing within the CASMACAT and SEECAT projects.

Keywords: translation tools, post-editing, computer-based translation, translation memory systems, machine translation, re-mediation.

DOI: https://doi.org/10.32782/2410-0927-2020-12-2

УДК 811.111 '373(045)

Наталія Білоус, Наталія Новохатська

\title{
НЕОЛОГІЗМИ ЯК ЗАСІБ ВІДОБРАЖЕННЯ СУЧАСНОГО СПОСОБУ ЖИТТЯ НОСЇ̈В АНГЛІЙСЬКОЇ МОВИ
}

Стаття визначає міленіалів як покоління, народжене після 1981 року, з глибокою залежністю від цифрових технологій, соціальними та економічними проблемами, яке переймається питаннями забруднення навколишнього середовища, проблемами соціальної нерівності та дискримінації. Іншими термінами на позначення цього покоління є: покоління Y, NEXT, селфі, ехо-бумери, мережеве або цифрове покоління, що підкреслює глибоку залежність міленіалів від цифрових технологій. Саме це покоління активно впливає на зміни лексичного складу мови через призму своєї мовної ментальності, що і призводить до появи неологізмів (слів чи сполук, використаних мовою в певний період на позначення нового або вже наявного поняття в новому значенні, які усвідомлюються носіями мови). У цьому дослідженні неологізми класифіковано за такими тематичними групами: 1) способи подолання стресу (лексеми та словосполучення, що позначають способи відновлення душевної рівноваги у зв'язку 3 незадоволенням результатами соціальної та професійної діяльності, неможливістю розв'язати поставлені завдання, браком часу, відсутністю можливості емоційних проявів): а) методика, б) тварина, в) людина; 2) ефективний таймменеджмент (неологізми на позначення швидкого темпу життя, постійного дефіциту часу i необхідності

(C) Білоус Н., Новохатська Н., 2020 
раціонального планування); 3) здоровий спосіб життя (лексичні одиниці на позначення свідомих підходів до харчування, нових видів спорту та відпочинку): а) спосіб харчування, б) види спорту, в) способи відпочинку; 4) взаємовідносини (новоутворення, які відображають демократичні принципи, боротьбу 3 гендерними стереотипами, важливість індивідуальності та самовираження): а) принципи виховання дітей, б) принципи взаємовідносин чоловік/жінка, в) боротьба з упередженостями; 5) житлові умови (одиниці на позначення економії на житловій площі, пріоритетності інфраструктури та району, можливості дистанційної роботи, енергоефективності та переробки відходів); 6) ставлення до навколишнього середовища (неологізми на позначення способів захисту навколишнього середовища).

Ключові слова: міленіали, неологізм, тематичні групи, мовні зміни.

Вступ. За останні два десятиліття лексична система більшості мов світу, зокрема англійської, зазнала значних змін. Науковці пов'язують це з політичними, економічними та культурними трансформаціями в суспільстві епохи стрімкої глобалізації світу. Свідченням постійних змін у мові $€$ виникнення неологізмів (слів чи сполук, використаних мовою в певний період на позначення нового або вже наявного поняття в новому значенні, які усвідомлюються носіями мови [4, с. 417]), які передусім засвоюються та закріплюються у мові чатів, соціальних мереж, Інтернет-статей та відображають спосіб життя та мислення носіїв сучасної англійської мови. Отже, актуальність роботи полягає в необхідності встановити причини та джерела поповнення складу мови новоутвореннями та визначити основні тематичні групи залежно від сфери їх функціонування.

Традиційно неологізми вивчалися за окремими аспектами: словотвірним (Ю. К. Волошина, А. О. Брагіна), функційним (О.В.Волостних, В. А. Голець, О. І. Дзюбіна), екстралінгвістичним (I. М. Чурилова), психолінгвістичним (С. І. Тогоєва, В. В. Петров), соціолінгвістичним (Л. П. Крисін, О. Д. Дуліченко) та прагматичним (О. І. Дзюбіна) тощо. В останні роки вони досліджені також на основі комплексного підходу [1].

Метою статті $є$ визначення основних тематичних груп англійських неологізмів на позначення способу життя носіїв англійської мови.

Поставлена мета передбачає розв'язання таких завдань: 1) здійснити вибірку неологізмів у Cambridge Dictionary за 2017-2020 роки; 2) визначити причини появи неологізмів у мові; 3) класифікувати неологізми на позначення способу життя носіїв англійської мов.

\section{Результати та дискусії.}

Зміна поколінь та епох призводить до зміни мови загалом та ії лексичного складу зокрема. Кожне покоління відображає картину навколишньої дійсності через призму своєї мовної ментальності. На даному етапі розвитку суспільства таким поколінням $є$ покоління "міленіалів".

Термін "міленіали” (від лат. Millennium - тисячоліття) був введений в науковий обіг американськими дослідниками Вільямом Штраусом і Нілом Хоув у кінці минулого століття [3] на позначення дітей, які народилися після 1981 року і повинні були закінчити середню школу на рубежі століть. Іноді їх називають поколінням Y, NEXT, селфі, ехо-бумерами, мережевим або цифровим поколінням, підкреслюючи глибоку залежність міленіалів від цифрових технологій. Окрім орієнтації на цифрові технології та соціальні мережі, покоління міленіалів характеризується готовністю до початку самостійного життя на більш пізньому етапі порівняно 3 попереднім поколінням. Передусім це пов'язано з соціальними та економічними проблемами, світовою фінансовою кризою, зростанням безробіття, забрудненням навколишнього середовища, проблемами соціальної нерівності та дискримінації.

Це призводить до появи нових понять, які фіксуються в лексичній системі мови. Проаналізувавши неологізми, зазначені у Cambridge Dictionary [2] за 2017-2020 роки, їх було класифіковано за 6 тематичними групами.

1. Способи подолання стресу. Незадоволення результатами соціальної та професійної діяльності, неможливість розв'язати поставленні завдання, брак часу, відсутність можливості емоційних проявів призводять до виникнення стресів. Сучасна людина постійно перебуває в пошуках способів відновлення душевної рівноваги, на позначення яких виникли нові номінативні одиниці:

а) методики: rage room - кімната, у якій можна розбити всі предмети й дати вихід гніву за окрему плату; laughter club - методика лікування сміхом; forest therapy - методика, щэо 
передбачає медитацію в лісі; sound healing - методика лікування звуком; gong bath-медитація під звуки гонга;

б) тварина: therapet - тварина, як правило, собака, яка спеціально навчена для заспокоєння людей, щчо перебувають у стані стресу або тривоги;

в) людина: homework therapist - спеціаліст, який допомагає учням виконувати шкільні завдання та готуватися до іспитів, зменшуючи рівень стресу і тривоги.

2. Ефективний тайм-менеджмент. Швидкий темп життя призводить до постійного дефіциту часу i необхідності впровадження в життя раціонального планування. Через неправильний розподіл часу людина відчуває хронічну нестачу сну, що і відображається в таких неологізмах: social jetlag відчуття втоми через постійне недосипання, яке компенсується сном на вихідних; nap bar / sleep pod - місче для сну, яке людина може орендувати, аби перепочити протягом робочого дня; sleeponomics - кошти на товари для покращення сну. У більшості людей немає навіть часу, щоб читати книги, що й відображене таким неологізмом: tsundoku купівля великої кількості книжок, читати які немає часу.

Прикладами ефективної організації часу є micro-scheduling - похвилинне планування справ на день та timeboxing - похвилинне планування справ на тиждень.

3. Здоровий спосіб життя. Наразі стрес є щоденним негативним досвідом людини, яка шукає ефективні способи його подолання. Таким чином, люди почали свідомо підходити до харчування та власного здоров'я, що і знайшло своє відображення у появі неологізмів на позначення:

а) способу харчування: $\boldsymbol{L A L S}$ - абревіатура на позначення слабоалкогольних напоїв або страв з низьким вмістом иукру, паnogardening - дрібне садівництво, наприклад, вирощування рослин на балконі, waste bread - хліб, виготовлений з домішками вчорашнього хліба, DASH diet спосіб харчування, спрямований на зниження високого артеріального тиску;

б) видів спорту: wild cycling - катання на велосипеді по доріжках сільської місиевості, river bugging - сплав річкою з сильною течією у маленькому надувному човні, шо має форму крісла, entertrainment - фітнес у поєднанні з розвагами, heli-yoga - заняття йогою на борту гелікоптера, fitness snacking - регулярне заняття фітнесом короткими інтервалами, іттегsive yoga - йога, що супроводжується аудіо та візуальним рядом для медитаиії, plogging - поєдання пробіжки зі збирання сміття;

в) способів відпочинку: daycation - відпочинок у готелі протягом одного дня, maternymoon - відпустка, яку проводить сім'я, поки мати перебуває в декретній відпустиі, daddymoon - відпустка чоловіка, який незабаром стане батьком і яка сприймаєтся як останній шанс відпочити з друзями до народження дитини, buddymооп - медовий місяць, на який запрошують друзів подружньої nари, skip-gen trip - відпустка, під час якої представники різних поколінь однієї сім'ї відпочивають окремо, slow adventure - тип відпочинку на свіжому повітрі, що дозволяє очінити навколишнє середовище та не передбачає великої фізичної активності, globo - людина, яка живе чи проводить багато часу в різних частинах світу, last-chance tourism - відвідування частин світу, які перебувають під загрозою зникнення.

4. Взаємовідносини. Міленіали в наш час намагаються будувати відносини на демократичних принципах, не піддаватися гендерним стереотипам, прагнуть пробувати щось нове, підкреслювати важливість індивідуальності та самовираження, шукати компроміс та фіксувати події свого життя на телефон, який завжди мають під рукою. Відповідно все вищезазначене призвело до появи таких лексичних одиниць:

а) принципи виховання дітей: free-range parenting - спосіб виховання, при якому дітям дозволясться приймати власні рішення без надмірного контролю і нагляду з боку батьків, рапda parenting - спосіб виховання, який передбачає заохочення дітей до незалежності та відповідальної поведінки з раннього віку, при иььму дітям дозволяють робити власні помилки, титsplainerмати, яка дає небажані поради або розповідає про вагітність, пологи тощь людині, часто вагітній жіниі або батькові, parennial - батьки, народжені впродовж 1980 - 2000-х років;

б) принципи взаємовідносин чоловік/жінка: $\boldsymbol{L A T}$ - абревіатура на позначення відносин, коли партнери прожсиають окремо, stashing - приховування інформащії про людину, з якою перебуваєте в романтичних стосунках; 
в) боротьба з упередженостями: ladydata - результати дослідження того, як будь-які зміни до бюджету впливають на жінок, шотепотісs- діяльність уряду, спрямована на забезпечення роботою більшої кількості жінок, особливо на високому рівні, bropropriation / hepeating - ситуачія, коли чоловік видає жіночу ідею за свою, Waspi (women against state pension inequality) - рух жінок проти пенсійної нерівності, flexism - дискримінація людей, які працюють за гнучким графіком.

5. Житлові умови. Сучасне покоління молодих людей, обтяжене великою кількістю кредитів та боргів, намагається заощаджувати на житлі. Це можуть бути невеликі за площею квартири на кшталт twodio - невелика квартира з однією великою кімнатою, ванною кімнатою та кухнею, спільними для щуе однієї квартири; microflat - дуже маленька квартира, зазвичай у великих містах, де не вистачає житла для всіх людей, які там живуть. При цьому умови проживання, територія, район, інфраструктура та можливість працювати дистанційно залишаються важливими, що й пояснює тенденцію появи таких неологізмів: smart city - cucmeмa взаємодії між містом та його жителями за допомогою сучасних інформачійно-комунікачійних технологій, superblock - закрита територія в місті, щчо складається з декількох кварталів, при иьому потреби людей, які там проживають, пріорітетні; со-hо-одночасна купівля сусідніх будинків декількома людьми з метою створення спільної громади й інфраструктури, shofficeсарай/гаражс, переобладнаний в офіс; shedio - сарай/гараж, переобладнаний в студію для занять музикою або іниим видом мистецтв. Екологічність житла також залишається важливою, а ключовими факторами при його виборі є енергоефективність та переробка відходів: super-home будинок, який використовує дуже мало енергії, оскільки був побудований з використанням новітніх технологій; corkitecture - використання пробки як будівельного матеріалу.

6. Ставлення до навколишнього середовища. Переважна більшість міленіалів переймається проблемами захисту навколишнього середовища, вважаючи людську діяльність основною причиною кліматичних змін. Ця проблема має своє відображення в усіх сферах людського життя: planetary health diet - спосіб харчування, який має на меті забезпечити всіх у світі достатньою кількістю їжі, не завдаючи шкоди планеті; green screеn-велика сталева сітка, густо вкрита плющем, щзо перешкоджає забрудненню повітря; precipitation whiplash період спекотної сухої погоди, щзо супроводжується періодом дощчів, який вважається наслідком кліматичних змін; climate gentrification - процес, внаслідок якого територія, що менше страждає від змін клімату, перетворюється з бідної на багатшу; hothouse earth ситуачія, коли вже не можна буде контролювати зміни клімату, внаслідок якої великі райони Землі стають непридатними для життя, ecological grief - відчуття жалю з приводу значних кліматичних змін, flight shaming- критика людей, щэо подорожують літаками, які забруднюють навколишнє середовище.

Висновки. Аналіз ілюстративного матеріалу свідчить про те, що у зв'язку 3 економічними, соціальними, політичними та культурними змінами у суспільстві відбувається постійне поповнення словника англійської мови неологізмами, які передусім відображають сучасний спосіб життя носіїв мови: способи подолання стресу, ефективний тайм-менеджмент, здоровий спосіб життя, взаємовідносини, житлові умови, ставлення до навколишнього середовища. Однак існує ще декілька груп неологізмів, пов'язаних зі стрімким розвитком технологій, активним використанням соціальних мереж, що впливає на появу нових способів просування та продажу товарів, появою нових видів злочинів, аналіз яких становить перспективу подальших досліджень.

References

1. Bilous, Nataliia, Novokhatska, Nataliia. 2018. "Sposoby tvorennia i funktsii anhliyskykh vidonimnykh neolohizmiv z osnovamy OBAMA i TRUMP”. Naukovi zapysky Tsentralnoukrainskoho derzhavnoho pedahohichnoho universytetu imeni Volodymyra Vynnychenka. Seriya: Filolohichni nauky 165:380-384.

2. Cambridge Dictionary. https://dictionaryblog.cambridge.org/tag/neologisms.

3. Howe, Neil, Strauss, William. 2009. Millenials Rising : The Next Great Generation. New York: Knopf Doubleday Publishing Group.

4. Selivanova, Olena. 2006. Suchasna linhvistyka : terminolohichna entsyklopediia. Kyiv; Poltava: Dovkillya. 
Билоус Наталия, Новохатская Наталия. Неологизмы как средство отображения современного образа жизни носителей английского языка. Статья определяет понятие миллениалов как поколение, рожденное после 1981 года, и которое характеризуется глубокой зависимостью от цифровых технологий, социальными и экономическими проблемами, обеспокоеностью вопросами загрязнения окружающей среды, проблемами социального неравенства и дискриминации. Другими терминами для обозначения этого поколения являются: поколение Y, NEXT, Селфи, эхо-бумеры, сетевое или цифровое поколение, чем подчеркивается глубокая зависимость миллениалов от цифровых технологий. Именно это поколение активно влияет на изменение лексического состава языка сквозь призму своей языковой ментальности, что и приводит к появлению неологизмов (слов или словосочетаний, используемых в языке в определенный период для обозначения нового или уже существующего понятия в новом значении, которое осознается носителями языка). В этом исследовании неологизмы классифицированы по следующим тематическим группам: 1) способы преодоления стресса (лексемы и словосочетания, обозначающие способы восстановления душевного равновесия в связи с недовольством результатами социальной и профессиональной деятельности, невозможностью решить поставленные задачи, нехваткой времени, отсутствием возможности эмоциональных проявлений): а) методика, б) животное, в) человек; 2) эффективный тайм-менеджмент (неологизмы для обозначения быстрого темпа жизни, постоянного дефицита времени и необходимости рационального планирования) 3) здоровый образ жизни (лексические единицы для обозначения сознательных подходов к питанию, новых видов спорта и отдыха): а) способ питания, б) виды спорта, в) способы отдыха; 4) взаимоотношения (новообразования, которые отражают демократические принципы, борьбу с гендерными стереотипами, важность индивидуальности и самовыражения): а) принципы воспитания детей, б) принципы взаимоотношений мужчина / женщина, в) борьба с предвзятостями; 5) жилищные условия (единицы для обозначения экономии на жилой площади, приоритетности инфраструктуры и района, возможности дистанционной работы, энергоэффективности и переработки отходов); 6) отношение к окружающей среде (неологизмы для обозначения способов защиты окружающей среды).

Ключевые слова: миллениалы, неологизм, тематические группы, языковые изменения.

Bilous Natalia, Novokhatska Natalia. Neologisms as Means to Reflect Native English Speakers' Modern Way of Life. The present article defines the notion and concept of millennials as a generation born after 1981 and characterizes it as a generation with a deep dependence on digital technologies, social and economic problems that is concerned with problems of environmental pollution, social inequality and discrimination. Other terms to denote this generation are: generation Y, NEXT, Selfie, echo boomers, network or digital generation, which emphasize deep dependence of millennials on digital technologies. It is this generation that actively influences changes in the lexical structure of the English language via their linguistic mentality. This processes lead to the emergence of neologisms (words or compounds used in a language in a certain period to refer to a new or existing concept in a new meaning, which are understood by native speakers). Based on the list of neologisms from the Cambridge Dictionary this study has classified them into the following thematic groups: 1) ways of overcoming stress (lexemes and phrases, denoting ways to restore mental balance caused by dissatisfaction with the results of social and professional activity, inability to solve tasks, lack of time and opportunities): a) methods, b) animal, c) human being; 2) effective time management (neologisms to indicate a fast pace of life, a constant shortage of time and the need for rational planning); 3) healthy lifestyle (lexical units denoting conscious approaches to eating, new sports and leisure time activities): a) diet, b) sports, c) leisure time activities; 4) relationships (new words reflecting democratic principles, overcoming gender stereotypes, importance of individuality and self-expression): a) principles of parenting, b) principles of relations between men and women, c) overcoming gender inequality; 5) living conditions (units which emphasize efforts to economize on accommodation, priority of infrastructure and district, remote work opportunities, energy efficiency and waste recycling); 6) attitude to the environment (neologisms designating environmental changes and ways to protect and enhance the environment to prevent risk of harm to human health).

Keywords: millennials, neologism, thematic groups, language changes.

DOI: https://doi.org/10.32782/2410-0927-2020-12-3

УДК 811.111 '42

Валентина Бойчук, Наталія Сфремова

\section{ОСОБЛИВОСТІ ЦДЕНТИФІКАЦЇ̈ ПЕСИМІЗМУ ПЕРСОНАЖА В ТЕКСТІ ХУДОЖНЬОГО ТВОРУ (НА МАТЕРІАЛІ АНГЛІЙСЬКОЇ МОВИ)}

Стаття присвячена висвітленню особливостей ідентифікації песимізму персонажа в тексті художнього твору. Художній текст є узагальненим образним відображенням дійсності у всьому різноманітті ії індивідуальносоціальних виявів. Оскільки аналізовані фрагменти художніх творів є стилізованим мовленням, розглядаємо художній текст як відображену реальність, що експлікує окремі фрагменти дійсності та фіксує реальні комунікативні ситуації, набуваючи при цьому певного прагматичного потенціалу. Аналіз лексичного контексту дозволив виявити набір мовних засобів, які безпосередньо або опосередковано вказують на песимістичні диспозиції, атрибуції, настрій або когнітивні стратегії персонажа художнього твору.

(C) Бойчук В., Сфремова Н., 2020 